\title{
Challenges and Opportunities in Employing Locals in the Construction Industry: Saudi Arabia Case
}

\author{
Mazen A. Al-Sinan ${ }^{1, *}$, Abdulaziz A. Bubshait ${ }^{2}$ \\ ${ }^{1}$ Contracting Department, Saudi Aramco, Dhahran 31311, Saudi Arabia \\ ${ }^{2}$ King Fahd University of Petroleum and Minerals, Dhahran 31261, Saudi Arabia
}

Received June 14, 2021; Revised July 26, 2021; Accepted August 22, 2021

\begin{abstract}
Cite This Paper in the following Citation Styles
(a): [1] Mazen A. Al-Sinan, Abdulaziz A. Bubshait, "Challenges and Opportunities in Employing Locals in the Construction Industry: Saudi Arabia Case," Universal Journal of Management, Vol. 9, No. 5, pp. 129 - 139, 2021. DOI: 10.13189/ujm.2021.090501.
\end{abstract}

(b): Mazen A. Al-Sinan, Abdulaziz A. Bubshait (2021). Challenges and Opportunities in Employing Locals in the Construction Industry: Saudi Arabia Case. Universal Journal of Management, 9(5), 129 - 139. DOI: 10.13189/ujm.2021.090501.

Copyright $\odot 2021$ by authors, all rights reserved. Authors agree that this article remains permanently open access under the terms of the Creative Commons Attribution License 4.0 International License

\begin{abstract}
The construction industry in Saudi Arabia represented around $5.5 \%$ of the gross domestic product (GDP) in 2019 and employed around $26.4 \%$ of the total workforce in the Saudi private sector; however, only $12.5 \%$ of the construction workers are locals. In 2020, unemployment has reached $15.4 \%$ among Saudi nationals. Concurrently, approximately 6.7 million workers in the Saudi private sector are non-locals. This paper investigates the challenges and opportunities of employing locals in the construction industry. A quantitative analysis of the public statistics is conducted to determine the genuine challenges and potential opportunities in replacing non-locals with locals in the construction industry. The analysis reveals that although most of the Saudi construction industry workforce $(87.5 \%)$ are non-local, the construction industry practically can accommodate around $9.5 \%$ of unemployed Saudis annually based on the current distribution of unemployed Saudis and the construction labor market. The analysis, also reveals that most unemployed Saudis are college graduates with majors that do not fit to find, suitable jobs in the construction industry. Among the findings that the Saudi construction industry will continue to need a non-Saudi workforce. Furthermore, though most unemployed Saudis are college graduates, there is a shortage of Saudis with appropriate training and academic majors.
\end{abstract}

Keywords Unemployment, Labor $\quad$ Market,
Construction Market, Saudi Arabia

\section{Introduction}

One of the challenging objectives of the Saudi 2030 Vision is to reduce the unemployment rate among Saudi citizens. According to the Saudi General Authority for Statistics (GASTAT) unemployment among Saudis reached $15.4 \%$ in the second quarter of 2020. COVID-19 might have contributed to the increase in unemployment, but the rate among Saudis was at a high of roughly $12 \%$ in 2019. Unemployment in Saudi Arabia is not due to a lack of jobs. According to the General Organization for Social Insurance (GOSI) statistic report for 2020, the total number of employees in the Saudi private labor market is around 8.65 million employees, with only around 1.90 million being Saudi. This leaves a huge gap in resolving the unemployment problem by replacing foreign workers with Saudi nationals.

The construction industry in Saudi Arabia represented around 5.5\% of the gross domestic product (GDP) in 2019 and employed around $26.4 \%$ of the total workforce in the Saudi private sector.

In the second quarter of 2020, around 2.28 million employees were working in the construction industry; around 285 thousand were Saudis, which means that Saudis represent around $12.5 \%$ of the total workforce in the construction industry [9].

The Saudi Ministry of Human Resources mandates a quota for the percentage of Saudis in construction firms that range between $8 \%$ to $13 \%$. These figures augment anecdotes from construction firms about employing the 
minimum mandated number of national employees merely to meet the regulations, which has led to "phantom employment." [7].

This paper presents a quantitative analysis of national statistics to uncover the obstacles to employing Saudis in the construction industry and proposes some recommendations to expand employment opportunities for Saudis in the industry. The paper explores the potential reasons for the low participation of Saudi nationals in the construction industry as a preliminary step to create employment opportunities.

\section{The Nature of the Construction Industry}

The literature that addresses the employment of Saudi nationals in the construction industry focuses on legislation without considering the inherent uniqueness of the construction industry $[1,2,4,5,6,7]$. The construction industry has many characteristics, which make it unique in more than one aspect compared to other industries. For one, the construction industry is more susceptible to economic fluctuations than other industries. This instability can be seen at the construction firm (micro-level) and industry (macro-level) levels. The construction industry is often severely affected during any recession or economic stagnation [13].

The construction industry is also labor-intensive, where the cost of labor ranges from $20 \%$ to $40 \%$ of the total project cost. Simultaneously, the construction industry is competitive, which makes optimizing labor costs essential.

Instability of employment is another important aspect, as construction firms face difficulty in retaining their workforce during the interim between projects. At the same time, there is no guarantee that the construction firm will win a new project on time to sustain its workforce. During the execution of the project, the demand for a workforce progresses in a bill shape. The construction industry employs a variety of skill sets, and each project is unique, which may require special skills. There is also mobility in the construction industry, as the workforce must move from one location to another following each project. In addition, the construction industry is susceptible to weather.

For a job seeker, job insecurity, mobility, and safety hazards make construction unattractive for employment when there are other alternatives unless there are attractive incentives.

\section{The Saudi Construction Labor Market}

The Saudi construction labor market is dominated by the foreign workforce. There is more diversity of nationalities in engineering, professional, and management jobs. The workers in the construction industry usually have an employment contract for one or two years. Some construction firms provide mainly manpower as a subcontractor to main contractors. The foreign workers should have an active employment contract to stay in the country; otherwise, the workers would have to leave the country. The employer has more flexibility to lay off foreign workers, while this might not be the case with Saudi nationals.

In recent years, the Saudi government has introduced some regulations that restrict contractors from hiring laborers from abroad. The driver for this is basically to assist in alleviating the problem of unemployment among local youths. All companies are required to employ a certain percentage of Saudi citizens before they can apply for visas for expatriate workers. The higher cost of Saudis versus non-Saudis discourages firms from hiring Saudis. The Ministry of Human Resources realized this and adopted a policy to close the gap between Saudis and non-Saudis revolving around increasing certain fees imposed on non-Saudi workers such as work permits and visas. This policy might be more effective for low-paid jobs. In fact, in 2017, the government began to implement an expat levy to close the gap between the cost of Saudis and non-Saudis.

Interviews with contractors indicated that they have difficulty in hiring Saudi nationals. In the first place, Saudi nationals are not interested in employment in the construction industry because it is difficult work, and they prefer to perform white-collar jobs. Furthermore, interviewees indicated that young Saudi nationals need extensive training, an unattractive prospect since the contractor risks losing the worker after investing in his training. While it is difficult for a non-Saudi worker to break his employment contract (which usually lasts for two years), a Saudi worker can leave his/her job at any time [3].

The contractors are not able to pay satisfactory salaries to Saudi nationals. In Saudi Arabia, there is no minimum wage for either Saudis or non-Saudi workers; however, wages are conventionally based on the nationality of the worker. It seems that the cost of a Saudi worker in comparison with his non-Saudi counterpart is one of the main issues. Some contractors indicated that they are forced to hire Saudis merely to satisfy government requirements. Hiring Saudis is an additional cost for them, especially when the utilization of Saudis is not as optimal as that of non-Saudi labor [3].

\section{Methodology}

This study's methodology is a deductive analysis of the official statistics published by the Saudi government 
agencies. The authors propose the following conceptions as potential reasons for the low participation of Saudi nationals in the construction industry:

1. Construction firms do not prefer to hire Saudis due to:

a Higher cost of Saudis versus non-Saudi workers (cost).

b Lack of Saudis with appropriate skills and training

c Lower productivity of Saudis versus non-Saudis workers.

d Legal burdens in laying off Saudis versus non-Saudi workers

e More flexibility of Saudis to leave work at any time (retention)

f Unavailability of Saudis willing to work in the construction industry

2. Saudis do not prefer to work in the construction industry due to:

a Job insecurity

b Relocation of Work Site (Mobility)

c Low salaries

d Hardship and safety hazards

e Lack of training

f Fewer opportunities to progress

This paper analyzes the above conceptions. Some of the above reasons could be interrelated; for example, productivity, training, and cost have interconnected effects. Therefore, some of the above will be jointly analyzed, e.g., the cost of Saudi workers as a potential obstacle for the employer and low salary as an obstacle to the employee. The availability of skilled Saudi workers and lack of training will also be addressed jointly.

In the next sections, the 12 potential obstacles are addressed under the following headings: (1) cost of Saudi worker, (2) availability and training of Saudi worker, (3) productivity of Saudi workers, (4) retention and legal burdens, and (5) job security, mobility, hardships, and safety hazards.

\section{Analysis}

\subsection{Cost of Saudi Workers}

In general, there is a big variance between the salaries of Saudi and non-Saudi workers. The monthly salary in Saudi riyals for different categories is presented in Figure
1. There are no reliable statistics for monthly salaries in terms of specific jobs. The GOSI statistics provide the overall average based on the basic salary without accounting for other benefits and expenses.

The results of the construction sector survey conducted by GASTAT in 2018 revealed that the average annual construction worker compensation was SAR 32.2 thousand, which is around USD 2,700 per month. In 2020, the GOSI reported that the average monthly salary for Saudis in the private sector was SAR 7,214, while the average monthly salary for non-Saudi is SAR 4,579 . The average monthly salary can only provide the general trend of the market [10].

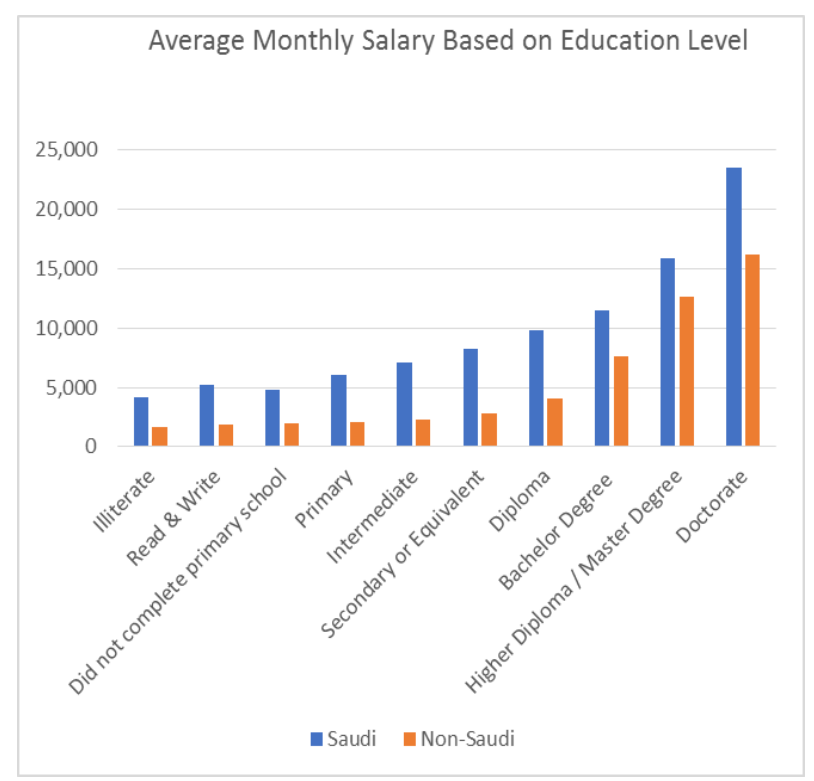

Figure 1. Average Monthly Salary in Saudi Riyal Based on Education Level; Source: GOSI (2020)

The gap between the cost of Saudi and non-Saudi becomes less at the higher level of the hierarchal ladder and can be in favor of non-Saudis at professional and management levels in some cases.

There are no statistics on the workforce skills within the Saudi construction industry. The 2018 GASTAT survey of the construction industry provided statistics on the occupational group within the construction industry but proved too broad (Table 1). The occupational groups still provide indications of the distribution of the construction workforce. The survey shows that most of the workforce is essentially primary occupations, representing unskilled laborers. The percentage of unskilled laborers was around $43 \%$ of the total construction workforce in 2018. 
Table 1. Number of Saudi and Non-Saudis Employees by Occupation

\begin{tabular}{|c|c|c|c|c|}
\hline Occupation * & Saudi & Non-Saudi & Total & Minimum Education Level $* *$ \\
\hline Management & 8,423 & 26,605 & 35,028 & Bachelor's Degree \\
\hline Specialist & 12,625 & 120,217 & 132,842 & Bachelor's Degree \\
\hline Technicians & 51,496 & 201,043 & 252,539 & Diploma \\
\hline The Scribes & 44,531 & 32,499 & 77,030 & Intermediate School \\
\hline Occupations of Services & 147,059 & 115,855 & 262,914 & Intermediate School \\
\hline $\begin{array}{c}\text { Machinery and Assembly } \\
\text { Workers }\end{array}$ & 148,799 & $1,122,653$ & $1,271,452$ & Intermediate School \\
\hline Primary Occupations & 6,134 & $1,504,058$ & $1,510,192$ & Less than Primary School \\
\hline Total & 419,067 & $3,122,930$ & $3,541,997$ & \\
\hline
\end{tabular}

Source: GASTAT (2018)

* titles are from the source (English version)

***Based on the Saudi Unified Occupational Classification

Table 2 shows the differences in monthly salaries between Saudis and non-Saudis based on education level for those fit to be classified as unskilled laborers. Though there are other expenses related to hiring non-Saudis, such as recruitment fees, airfare, work permits, visas, and accommodations, there are also additional expenses to hiring Saudis, such as GOSI contributions, which are around $11 \%$ of the Saudi monthly salary and has to be paid by the employer. Overall, the cost of Saudis remains much higher than the cost of non-Saudis.

Table 2. The Average Monthly Salary of Saudi and non-Saudis in Saudi Riyal for Low Level of Education

\begin{tabular}{|c|c|c|c|}
\hline Level of Education & Saudi & Non-Saudi & Differential \\
\hline Illiterate & 4,165 & 1,650 & $252 \%$ \\
\hline Read \& Write & 5,215 & 1,872 & $278 \%$ \\
\hline $\begin{array}{c}\text { Less than Primary } \\
\text { School }\end{array}$ & 4,777 & 2,008 & $238 \%$ \\
\hline Primary & 6,058 & 2,053 & $295 \%$ \\
\hline
\end{tabular}

Source: GOSI (2020)

Table 3 shows a comparison of the salaries for other occupations, including technicians, scribes (clerks), services, and machinery who can be classified as skilled laborers. The education level for skilled laborers is intermediate, high school, or diploma. Similarly, the cost of Saudis is much higher than the cost of non-Saudis for those who have the level of education, qualifying them as "skilled laborers."

Table 3. The Average Monthly Salary of Saudi and non-Saudis in Saudi Riyal for Skilled Laborers

\begin{tabular}{|c|c|c|c|}
\hline $\begin{array}{c}\text { Level of } \\
\text { Education }\end{array}$ & Saudi & Non-Saudi & Differential \\
\hline Intermediate & 7,138 & 2,261 & $315 \%$ \\
\hline $\begin{array}{c}\text { Secondary or } \\
\text { Equivalent }\end{array}$ & 8,198 & 2,762 & $297 \%$ \\
\hline Diploma & 9,807 & 4,104 & $239 \%$ \\
\hline
\end{tabular}

Source: GOSI (2020)

Table 4 shows the monthly salary differences between
Saudis and non-Saudis for those who have the education, qualifying them to be specialists or managers, where a bachelor's degree is the minimum education. For this category, the cost of Saudis is not as high in comparison with other categories (i.e., unskilled laborers, skilled laborers, and technicians). Management and specialists represent less than 5\% of the Saudi construction industry's total workforce.

Table 4. The Average Monthly Salary of Saudi and non-Saudis in Saudi Riyal for Specialist and Management

\begin{tabular}{|c|c|c|c|}
\hline $\begin{array}{c}\text { Level of } \\
\text { Education }\end{array}$ & Saudi & Non-Saudi & Differential \\
\hline Bachelor's Degree & 11,524 & 7,625 & $151 \%$ \\
\hline $\begin{array}{c}\text { Higher Diploma / } \\
\text { Master's Degree }\end{array}$ & 15,863 & 12,620 & $126 \%$ \\
\hline Doctorate & 23,505 & 16,240 & $145 \%$ \\
\hline
\end{tabular}

Source: GOSI (2020)

The above comparison confirms that the employment of non-Saudis is more cost-effective to the employer without considering other factors such as workmanship, productivity, and competencies, which might also be in favor of non-Saudis.

According to the US Bureau of Lobar Statistics, the average hourly wage in the construction industry was USD 20.06 in 2019[12]. In contrast, the average hourly wage of the Saudi construction industry was roughly USD 6.75 in 2018. The labor cost in Saudi Arabia is much lower than the labor cost in the USA as well as other advanced countries. This should make the construction cost in Saudi Arabia much lower than the cost in the USA and other advanced countries. Although, comparing the cost of construction is not a straightforward exercise, and the only accurate comparison would be comparing identical facilities with the same materials, quality, and specifications. However, there are some indications that the construction cost in Saudi Arabia, in general, is lower than the construction cost in the USA and other advanced countries (e.g., Japan and Germany). The USA and advanced countries were utilized as benchmarks because 
the GDP per capita in Saudi is comparable to that of advanced countries.

In summary, increasing the participation of Saudi workers in the construction industry will increase the construction cost for owners. There will be a proportional increase in the construction cost as Saudi workers' participation increases.

Figure 2 shows the impact of the increase in Saudi participation in the construction industry on construction costs, not considering productivity. As a worst-case scenario, the following assumptions were made to predict the impact of increasing Saudis on the construction cost (Figure 2):

\section{Construction Cost $=$ Labor Cost + Other Cost \\ Lobar Cost $=30 \%$ of the total cost}

Saudi Cost $=300 \%$ higher cost than non-Saudis

The assumption that labor cost is $30 \%$ is since the labor cost ranges between $20 \%$ to $40 \%$ of the construction cost. The assumption that the cost of Saudis is $300 \%$ higher than non-Saudis is based on the analysis and comparison between Saudi and non-Saudi, (Table 2, 3 and 4). Consideration is made to have Saudi wages on the higher side to attract Saudis to work in the construction industry. Construction firms are expected to pay Saudis more than other industries since working in the construction industry is more difficult and less attractive than other industries.

According to Figure 2, if the entire workforce in the Saudi construction industry was nationalized, the cost of construction would increase by around $60 \%$. For project owners, this is a significant increase, especially for residential projects where the owners are individuals.

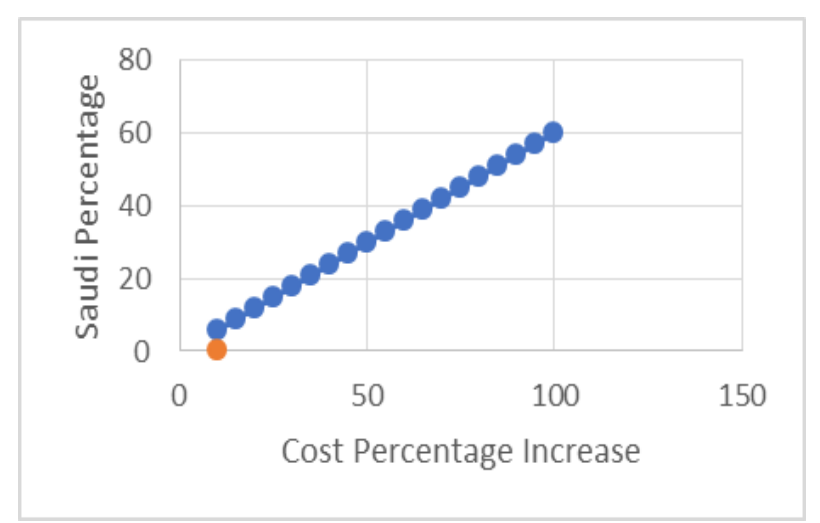

Figure 2. The impact of Saudi participation on the cost of the construction
Having an attractive salary would encourage Saudis to seek jobs in the construction industry. The construction industry has some similarities with the drilling industry regarding hardship, mobility, and safety hazards, yet Saudis are keen in seeking work with drilling companies both onshore and offshore due to the attractive compensation packages.

\subsection{Availability and Training of Saudi Workers}

Construction firms may encounter difficulty in recruiting Saudis since education among Saudis has expanded significantly over the past three decades. The Saudi construction industry depends mainly on unskilled $(\sim 43 \%)$ and skilled $(\sim 53 \%)$ laborers [13]. Table 5 shows extrapolated number of Saudis and non-Saudis by occupation in 2020. Adjustments have been made to consider the increased percentage of Saudis from $11.8 \%$ in 2018 to $12.5 \%$ in 2020 .

Table 5. Extrapolated Number of Saudis and Non-Saudis by Occupation in 2020

\begin{tabular}{|c|c|c|c|}
\hline Occupation & Saudi & Non-Saudi & Total \\
\hline Management & 6,605 & 19,004 & 22,610 \\
\hline Specialist & 9,577 & 76,836 & 85,413 \\
\hline Technicians & 35,053 & 128,496 & 163,549 \\
\hline Scribes & 30,343 & 20,772 & 51,114 \\
\hline $\begin{array}{c}\text { Occupations of } \\
\text { Services }\end{array}$ & 99,667 & 74,048 & 173,715 \\
\hline $\begin{array}{c}\text { Machinery and } \\
\text { Assembly } \\
\text { Workers } \\
\end{array}$ & 10,029 & 716,698 & 817,728 \\
\hline $\begin{array}{c}\text { Primary } \\
\text { Occupations } \\
\end{array}$ & 4,373 & 958,364 & 964,837 \\
\hline Total & 284,747 & $1,994,218$ & $2,278,965$ \\
\hline
\end{tabular}

According to the GASTAT, the percentage of unemployed Saudis is $15.4 \%$ in 2020 , which translates to around 1.33 million Saudis. However, most of the unemployment is among females $(64.1 \%)$, while the percentage of males is around $35.9 \%$, or roughly 478 thousand. Globally, due to the nature of the construction industry, the percentage of females does not exceed $10 \%$ [14.15]. This leads us to an unemployed pool of around 525 thousand available to the construction industry after excluding most unemployed females. However, the analysis of the education level of the unemployed Saudis (Figure 3), reveals that most unemployed Saudis hold a bachelor's degree (56.6\%). 


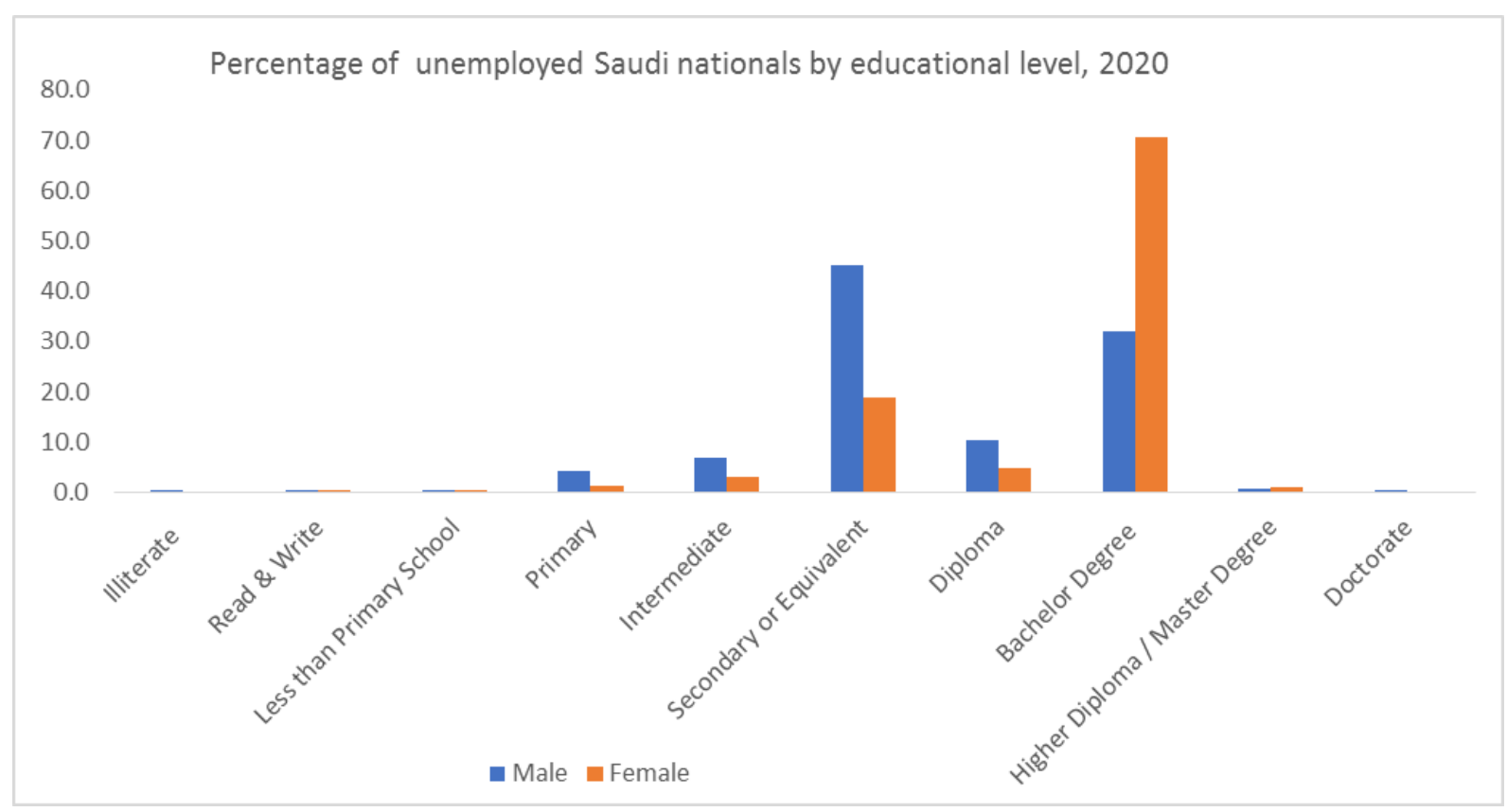

Figure 3. Percentage of Unemployed Saudi Nationals by Education Level; Source: GASTAT (2020).

Table 6 shows the number of unemployed Saudis by education level. The number of unemployed Saudi males whose education is lower than secondary school is around 57 thousand. Those with secondary school education or higher are not expected to work as unskilled laborers. The minimum requirements for primary occupation (unskilled laborers) are primary education or less. This shall drop available unskilled Saudis to around 23 thousand (around $1.7 \%$ of unemployed Saudis and $2.4 \%$ of non-Saudi unskilled laborers) those with intermediate school education are excluded. The number of unemployed Saudis males who completed secondary education or diploma is around 250 thousand. The number of unemployed Saudi males who hold bachelor's degrees or higher is around 157 thousand and who could work as specialists and management. In terms of specialists and management, females could also participate.

Table 6. Number of Unemployed Saudis Based on Education Level

\begin{tabular}{|c|c|c|c|}
\hline Education & Male & Female & Total \\
\hline Illiterate & 1,105 & 0 & 1,105 \\
\hline Read \& Write & 1,773 & 3,102 & 4,875 \\
\hline $\begin{array}{c}\text { Did not complete primary } \\
\text { school }\end{array}$ & 1,029 & 718 & 1,747 \\
\hline Primary & 19,588 & 12,081 & 3,1669 \\
\hline Intermediate & 33,265 & 25,862 & 59,127 \\
\hline Secondary or Equivalent & 216,298 & 161,746 & 378,044 \\
\hline Diploma & 48,838 & 39,974 & 88,812 \\
\hline $\begin{array}{c}\text { Higher Diploma / Master's } \\
\text { Degree }\end{array}$ & 152,444 & 601,919 & 754,363 \\
\hline Doctorate & 1,377 & 0 & 1,377 \\
\hline
\end{tabular}

The Saudi Unified Occupational Classification mandates a diploma as the minimum education level for a technician job. Simultaneously, intermediate school as a minimum requirement for scribes (clerk), services, and mechanics (e.g., equipment operator) [11]. These jobs can be considered skilled laborers.

Table 7 demonstrates the number of unemployed Saudis that are available to work in the construction industry.

Table 7. Number of Unemployed Saudis with Educational Requirements for each Occupation Group

\begin{tabular}{|c|c|c|c|}
\hline $\begin{array}{c}\text { Work } \\
\text { Category }\end{array}$ & $\begin{array}{c}\text { Current } \\
\text { Number of } \\
\text { Non-Saudi }\end{array}$ & $\begin{array}{c}\text { Available } \\
\text { Male }\end{array}$ & $\begin{array}{c}\text { Available } \\
\text { Female }\end{array}$ \\
\hline $\begin{array}{c}\text { Management/ } \\
\text { Specialist }\end{array}$ & 95,840 & 156,651 & 601,970 \\
\hline Technician & 128,496 & 48,838 & N/A \\
\hline Skilled & 811,518 & 249,563 & 20,770 \\
\hline Unskilled & 958,364 & 23,495 & N/A \\
\hline
\end{tabular}

Table 7 reveals that the pool of unemployed Saudis who can fit to replace non-Saudis unskilled laborers represents around only $2.5 \%$ of non-Saudi laborers. Around 250 thousand Saudi males and 20.8 thousand females are available to work as skilled laborers (clerks). This represents around 33\% of non-Saudi skilled laborers. However, young Saudis who join the construction industry need on-job training before assuming their jobs as full-fledged skilled laborers. The construction industry could absorb most Saudi males with intermediate and secondary certificates if they are interested in working in the construction industry. Additionally, up to 20,770 females can replace the current number of non-Saudi clerks.

Table 7 shows that around 128 thousand technicians are 
non-Saudis. However, to be a technician in the construction industry, you should have a suitable major. Similarly, for specialist and management jobs, the field of study should fit. Table 8 shows the distribution of unemployed Saudis of diploma holders and higher by major by percentage.

Table 8. Distribution of Unemployed Saudis of Diploma Holders and Higher by Major and Percentage

\begin{tabular}{|c|c|c|c|}
\hline Major & Male & Female & Total \\
\hline $\begin{array}{c}\text { Educational Sciences and } \\
\text { Teacher Preparation }\end{array}$ & 8.2 & 18.7 & 16.2 \\
\hline Arts & 0.3 & 1.1 & 0.9 \\
\hline Humanities Studies & 18.4 & 26.6 & 24.6 \\
\hline Behavioral Social Sciences & 2.9 & 7.0 & 6.0 \\
\hline Press and media & 1.2 & 0.8 & 0.9 \\
\hline Business and Management & 20.5 & 14.3 & 15.8 \\
\hline Law & 4.7 & 1.2 & 2.0 \\
\hline Life Sciences & 3.0 & 4.4 & 4.1 \\
\hline Physics & 2.9 & 6.0 & 5.2 \\
\hline Mathematics and Statistics & 1.7 & 2.8 & 2.5 \\
\hline IT and Computer science & 12.0 & 7.0 & 8.2 \\
\hline Engineering & 10.3 & 0.9 & 3.1 \\
\hline $\begin{array}{c}\text { Manufacturing and } \\
\text { Production Processes }\end{array}$ & 0.1 & 0.3 & 0.2 \\
\hline $\begin{array}{l}\text { Architecture and } \\
\text { Construction }\end{array}$ & 2.4 & 0.4 & 0.9 \\
\hline Veterinary & 0.0 & 0.0 & 0.0 \\
\hline Health & 8.4 & 4.6 & 5.5 \\
\hline Personal Services & 0.6 & 2.6 & 2.1 \\
\hline Transport Services & 0.1 & 0.0 & 0.0 \\
\hline Environment Protection & 0.2 & 0.1 & 0.1 \\
\hline Security services & 0.2 & 0.0 & 0.1 \\
\hline Agriculture & 0.6 & 0.0 & 0.2 \\
\hline Social Service & 1.2 & 1.3 & 1.3 \\
\hline Total & 100 & 100 & 100 \\
\hline
\end{tabular}

A review of Table 8 , reveals that only the following majors are suitable to be employed in the construction industry:

1. Business and Management

2. Law

3. Information Technology and Computer science

4. Engineering and Engineering professions

5. Architecture and Construction

While engineering and architecture and construction majors are required in the construction industry, other majors are required to a lesser degree. Table 9 shows the number of diploma holders or higher in the majors relevant to the construction industry.
Table 9. Number of Unemployed Saudi with a Diploma or Higher by Selected Majors

\begin{tabular}{|c|c|c|c|}
\hline Major & Male & Female & Total \\
\hline $\begin{array}{c}\text { Business and } \\
\text { Management }\end{array}$ & 41,920 & 93,291 & 135,211 \\
\hline Law & 9,543 & 7,805 & 17,348 \\
\hline $\begin{array}{c}\text { IT and Computer } \\
\text { Science }\end{array}$ & 24,506 & 78,153 & 102,659 \\
\hline Engineering & 21,022 & 5,698 & 26,720 \\
\hline $\begin{array}{c}\text { Architecture and } \\
\text { construction }\end{array}$ & 4,821 & 2,890 & 7,711 \\
\hline
\end{tabular}

The official published statistics do not provide the specific majors or the degree. However, the total number of unemployed with engineering and architecture, and construction major is around 34.4 thousand. This unemployed pool could be very suitable to replace non-Saudis who fall under technician, specialist, and management. Currently, there are around 95.8 thousand non-Saudis working as specialists and management. In addition, around 128.5 thousand non-Saudis are working as technicians. In addition, those with business, IT, and law majors could also work in the construction industry as specialists and management. However, the percentage of those majors will not exceed $15 \%$ of the total specialist and management. This assumption should increase the pool of unemployed Saudis who can replace non-Saudis to around 39.6 thousand.

Accordingly, in the ideal situation, the construction industry has an unemployed pool of 310 thousand Saudis, or roughly $23 \%$ of the total unemployed Saudis, which could increase the percentage of Saudis in the construction workforce by a total of $26 \%$. Realistically, this conclusion is impractical and cannot be achieved. The construction industry, especially for skilled and unskilled jobs, which represent most of the workforce, requires physical capabilities due to the harshness of the industry. The nature of the fieldwork in the construction industry discourages many individuals from entering construction not only due to job insecurity and mobility but also safety hazards. In addition, the industry is not ready to absorb a high number of untrained skilled and unskilled laborers instantaneously. Realistically, construction firms could replace an annual maximum of $10 \%$ of the skilled non-Saudi with in-training skilled Saudi, which is equivalent to around 81 thousand jobs.

For management and specialist jobs, the number of unemployed Saudis who are bachelor's degree holders or higher is large enough to replace all non-Saudis. Those with suitable majors are limited (around 34.4 thousand). In addition, it takes more than just education to replace non-Saudis. It is unrealistic to consider specialists and management as interchangeable employees. Having the appropriate experience and competencies is essential to replace non-Saudis with Saudis. Therefore, it is unrealistic to think of replacing non-Saudis within a short period. The industry could replace around $10 \%$ of non-Saudi 
specialists and management from the pool of qualified Saudis, which should employ around 9.6 thousand Saudis annually.

In 2020, the Ministry of Human Resources took the right step in this direction by mandating $20 \%$ of engineers in the construction and engineering sectors to be Saudis. This step will create jobs for most unemployed Saudi engineers, who number around 26.7 thousand.

Technician jobs that require a diploma, numbering 128 thousand non-Saudis, might be more challenging to replace with Saudis. The official statistics do not provide the number of unemployed with their diploma major. Most likely, there are enough Saudis out of the 34.4 thousand to replace $10 \%$ of the non-Saudi technicians. This is an ambitious target. This target could replace around 103.5 thousand non-Saudis annually. This does not consider the pool of 23,495 Saudis who are fit to work as unskilled laborers, which the industry can absorb. This should increase the percentage of Saudis in the construction industry from $12.5 \%$ to around $17.5 \%$ in one year. The gradual increase will not only preserve the industry from losing expertise but will also provide the market with room to adjust to the higher construction cost resulting from replacing non-Saudis with Saudis.

\subsection{Productivity of Saudi Workers}

The low productivity of Saudi laborers could be one of the reasons for not hiring Saudis in the construction industry.

The GASTAT 2018 survey of the construction industry reveals that the average weekly working hours of non-Saudis are generally more than Saudis in all job categories except management, where the average working hours are the same (Table 10). This does not indicate that the productivity of non-Saudis is higher than the productivity of Saudis. Per Saudi Labor Law, the weekly working hours is 48 hours, and workers should be compensated with overtime pay for extra hours.

Table 10. Average Weekly Working Hours by Occupation

\begin{tabular}{|l|c|c|}
\hline Occupation & Saudi & Non-Saudi \\
\hline Management & 48 & 48 \\
\hline Specialists & 54 & 53 \\
\hline Technicians & 54 & 58 \\
\hline The Scribes & 56 & 61 \\
\hline Services & 59 & 63 \\
\hline Machinery and Assembly Workers & 61 & 62 \\
\hline Primary Occupations & 65 & 70 \\
\hline Total & 57 & 59 \\
\hline
\end{tabular}

The results of 2018, the GASTAT survey of the construction industry, reported that the overall construction industry's average productivity is around SAR 93,300 per year. The report calculated the productivity by dividing the overall revenues of the construction firms by the number of workers. This formula provides only how much each employee generates for the firm (revenue per employee ratio). There are multiple formulas for measuring productivity in the construction industry. The common formula to calculate the productivity in construction is units of work produced per man-hour. The inverse of labor productivity, man-hour per unit is also common in construction. However, some contractors are more interested to measure productivity as units of output per dollar $[8,16]$ :

$$
\text { Labor Productivity }=\frac{\text { output }}{\text { Loabr cost }}
$$

Adopting the above formula and measuring the productivity for each activity could help develop a repository useful for project planners and cost engineers. In addition, it provides a more meaningful tool to benchmark the productivity of each worker based on his trade or discipline. With the above formula, labor productivity is affected by labor skills, incentives, appropriate tools and equipment, and management. Improving labor productivity is important to optimize the project cost. In addition, productivity should be monitored and measured routinely. The number of skilled Saudi laborers is currently low, and the industry hires Saudis basically to meet governmental requirements. The level of experience and training of skilled Saudi laborers have not been studied. Accordingly, the claim that Saudis are less productive is merely an assumption.

The general productivity of the construction workforce should be studied thoroughly. The size of the workforce in the Saudi construction industry seems to be inflated compared to other countries that have an even bigger size of construction market. In 2018, in the USA, the private construction industry spent around USD 992 billion, while the number of employees, according to the U.S. Bureau of Labor Statistics, was around 7.2 million. This means that the revenue generated by each worker in the U.S. construction is around USD 137.7 thousand (SAR 516 thousand), while in Saudi, it was around USD 26 thousand [12].

The GASTAT in 2018, in its survey of the construction activity, reported that the total workers in the construction industry were around 3.54 million, while the 2020 statistics estimate the number to be around 2.28 million. The construction industry contributed around SAR 151.5 billion in 2018 and SAR 163.6 billion in 2019. Therefore, the drastic decrease in the number of workers in the construction industry is not due to a decrease in demand but could be more related to the expat levy that the government implemented beginning July 2017. This could mean that the construction market was inefficient in utilizing its human resources due to the low cost of construction laborers.

As Saudis participate longer in the construction industry and gain more experience and training, their 
productivity shall increase.

\subsection{Retention and Legal Burdens}

While the employment regulations state that a two-month notice is required for Saudi workers to resign, it is a longer procedure for non-Saudi workers. This could be one of the non-critical factors for the preference towards non-Saudi. Any firm could retain its resources by providing competitive compensation and a healthy work environment. The government is in the process of canceling the sponsorship regulations and replacing them with employment agreements like the practices in most countries. This step will diminish one of the claimed reasons for the preference of non-Saudis. The new regulations are scheduled, tentatively, to take effect in 2021.

The instability of the construction industry makes construction firms more susceptible to lay off workers during downtim. The labor law has been changed to overcome some of the obstacles that private firms claimed to be reasons for their preference for non-Saudis.

\subsection{Job Security, Mobility, Hardship, and Safety Hazards}

Due to the nature of the construction industry, several factors could discourage Saudis from joining. Job security is most likely one of the major reasons. The construction industry's instability is inevitable, and construction firms cannot sustain their manpower over long durations. Management and key professionals have much more job security than unskilled and skilled laborers. However, in 2014, GOSI introduced an unemployment program, (SAND) which provides financial support for the Saudi workers during periods of unemployment for reasons out of their control, such as being laid off, until they are re-employed.

Mobility, hardship, and safety hazards could also be factors that discourage some Saudis, but they are not genuine obstacles. Around $62 \%$ of the total workforce in drilling (mining and quarrying) are Saudis [9]. The safety hazards and hardship in drilling and mining are not less than those in the construction industry, and the work locations are often remote, yet many Saudis are interested in working in those industries. Saudis are interested in working in those industries due to attractive salaries and job security.

\section{Findings and Recommendations}

\section{Findings}

Based on the above analysis, these are major findings:
1. There is a cost associated with replacing non-Saudi with Saudis in the construction industry. The maximum increase in the construction cost is around 3\% for each 5\% increase in Saudi participation per the analysis of replacing non-Saudis with Saudis.

2. The construction industry can accommodate around 103 thousand Saudis every year in technicians, specialists, and management workers. All unskilled unemployed Saudis (around 23 thousand) can be accommodated immediately.

3. The Saudi construction industry will continue to need non-Saudi unskilled laborers since the number of Saudis with a low-level education is negligible.

4. Though most unemployed Saudis are college graduates, there is a shortage of Saudis with appropriate training and academic to work in the construction industry.

5. There are some indications that the size of the construction workforce in Saudi Arabia is bigger than the size of construction activities. This could be due to multiple factors, such as low productivity, the construction methods, less utilization of machinery and technology, or the lack of a freelancer (seasonal) worker scheme.

6. No evidence supports the lower productivity of Saudi versus non-Saudi.

7. No evidence supports Saudis' disinterest in working in the construction industry due to its nature (mobility, hardship, safety hazards). The effect of job insecurity could not be measured.

\section{Recommendations}

The following are some recommendations based on the analysis:

1. Due to the fluctuation in the construction industry, it is unwise to aim, as a strategic goal, to fully nationalize the jobs in the construction industry. Having a percentage of temporary non-Saudis could be useful to stabilize the Saudi labor market during the recession without the need to lay off Saudis.

2. Mandating a quota of Saudis for selected trades will create a demand for Saudis, which should translate into attractive compensation and incentives for Saudis. In addition, the construction firms will cease having phantom employment since they will have no other alternative than hiring Saudis. The quota should be determined after ensuring that vocational and on-job training are available, and the number of available Saudi resources is sufficient to replace non-Saudis.

3. More Saudis should be directed toward construction-based vocational training, engineering disciplines, and, if possible, internships since there are enormous employment opportunities in the 
construction industry for those with the right skills and qualifications.

4. Each employee, whether Saudi or non-Saudi, should be assigned a specific work permit job code to have real-time statistics of the labor market, which is important to determine the areas of shortage and plan training and educational roadmaps to satisfy the market demand.

5. The qualifications for skilled jobs should be revisited and upgraded to enhance quality.

6. Periodical surveys of the construction industry should be conducted, analyzed, and benchmarked with other countries to improve the industry in general.

7. Measuring productivity in the construction industry should be conducted periodically using the Activity-Oriented Model. Also, there might be a need to establish a productivity center in Saudi Arabia.

\section{Conclusions}

This paper addresses the challenges of employing Saudi nationals and the potential opportunities for employing Saudis in the construction industry. The probable reasons for low Saudi participation in the construction industry were examined based on a quantitative analysis of the official published statistics. The analysis revealed that although most of the construction industry workforce $(87.5 \%)$ are non-Saudi, it can accommodate an annual $9.5 \%$ of unemployed Saudis. Currently, most of unemployed Saudis are college graduates with majors that do not fit suitable jobs in the construction industry.

As a strategic goal, the construction industry could accommodate a significant number of Saudis and help reduce unemployment drastically in the KSA. However, the process of introducing Saudis in the construction market should be gradual, and Saudis should be encouraged to enroll in majors befitting the construction market

\section{Acknowledgments}

The authors extend their gratitude and appreciation to Saudi Aramco for encouragement in publishing this technical paper.

\section{REFERENCES}

[1] Al-Emad, N. and Rahman, I.A., 2017. An initial investigation on the challenges of managing construction workforce in Saudi Arabia. IOP Conference Series: Materials Science and Engineering [online], https://iopscience.iop.org/article/10.1088/1757-899X/271/ $1 / 012033 / p d f$
[2] Al-Emad, N.H, and Rahman, I.A., 2018. Issues engulfed Saudi Arabia construction workers. IOP Conference Series: Earth Environmental Science [online], 140 (012097). Available from: https://www.researchgate.net/publication/324445078_Issu es_engulfed_Saudi_Arabia_construction_workers

[3] Al-Sinan, M.A., 2004. TQM and the construction industry: Saudi Arabia - a case study. Doctoral Dissertation (PhD). City University London. Available from: https://openaccess.city.ac.uk/id/eprint/8413/1/TQM_and_t he_construction_industry_-_Saudi_Arabia_a_case_study.p df

[4] Bel-Air, F.D., 2018. Demography, Migration and Labour Market in Saudi Arabia. Gulf Research Center GLMM - EN - No. 5/2018. Available from: http://gulfmigration.org/media/pubs/exno/GLMM_EN_20 18_05.pdf

[5] Hertog, S., 2018. Can We Saudize the Labor Market without Damaging the Private Sector? (Special Report). King Faisal Center for Research and Islamic Studies. Available from: http://kfcris.com/pdf/8fd49f41c540c860a49bcd8d4f2966a7 5be162612cffa.pdf

[6] The Labor Market in Saudi Arabia: Background, Areas of Progress, and Insights for the Future, 2018. Harvard Kennedy School. Evidence for Policy Design. Available from:

https://epod.cid.harvard.edu/sites/default/files/2019-08/EP D_Report_Digital.pdf

[7] Khoja, S., 2016. Saudi Arabia: Saudisation In the KSA Construction Industry [online].UK, Clyde \& Co. Available from:

https://www.mondaq.com/saudiarabia/employee-rights-lab our-relations/470342/saudisation-in-the-ksa-construction-i ndustry

[8] Shehata, M.E. and El-Gohary, K.M., 2012. Towards improving construction labor productivity and projects' performance. Alexandria Engineering Journal, 50, 321-330. Available from: https://www.sciencedirect.com/science/article/pii/S111001 6812000142

[9] The General Authority for Statistics, Labor market statistics Q2 2020. Available from: https://www.stats.gov.sa/en/34

[10] The General Authority for Statistics, Survey of Construction Activity 2018. Available from: https://www.stats.gov.sa/en/1004-0

[11] The Unified Saudi Occupational Classification. General Authority for Statistics. Available from: https://www.stats.gov.sa/sites/default/files/Report_GAStat $\%$ 20Unified\%20Saudi\%20Occupational\%20Classification _English_V1.pdf

[12] U.S. BUREAU OF LABOR STATISTICS [online] Available from: https://www.bls.gov/ [Accessed \# January 2021].

[13] D. Laquidara-Carr, 2019 "Understanding the Challenges of Recruiting New Workers to the Construction Industry" Construction Executive magazine. Available from:https://constructionexec.com/article/understanding-th 
e-challenges-of-recruiting-new-workers-to-the-constructio n-industry

[14] De Sousa, M. B and Matos, F.R (2017) "Every Female Engineer is a Survivor- A Study of Defense Strategies in the Work of Female Engineers", Universal Journal of Management 5(4): 175-180, 2017

[15] Slowey, K, 2019” By the numbers: Women in construction”,
Construction Dive. Available from https://www.constructiondive.com/news/by-the-numberswomen-in-construction/549359/

[16] Randolph H. Thomas, William F. Maloney, R. Malcolm, W. Horner, Gray R. Smith, Vir K. Handa, Steve R. Sanders 1990, Modeling construction labor productivity Journal of Construction Engineering and Management, ASCE, 116 (4) (1990), pp. 705-726 